TEME, г. XLI, бр. 4, октобар - децембар 2017, стр. 899-916

Прегледни рад

Примљено: 17. 3. 2017.

DOI: $10.22190 /$ TEME1704899J

Одобрено за штампу: 15. 11. 2017.

\title{
THE IMPACT OF CRISIS TRENDS IN BANKING ON EXPANDING FINANCIAL SAFETY NET
}

\author{
Mirjana Jemovič ${ }^{*}$, Borko Krstić \\ University of Niš, Faculty of Economics, Niš, Serbia \\ mirjana.jemovic@eknfak.ni.ac.rs
}

\begin{abstract}
Stable and efficient functioning of financial institutions, especially banking institutions, requires the existence of an adequate regulatory framework. The differences in the character and functioning of financial institutions caused differences in the regulatory approaches for maintaining stability and efficiency, whereby one should bear in mind that even within a concrete financial system, the regulatory framework evolves in order to be able to respond to new trends in the financial services sector. A growing homogenization of activities and a less noticeable difference among financial institutions caused the financial safety net to expand to non-bank financial institutions in order to maintain financial stability. The aim of this paper is to consider the justification and implications of such an expansion. Considering the fact that financial safety net „expansion“ stimulates riskier behaviour of protected institutions, this paper offers suggestions for dealing with this problem in order to reduce it as much as possible.
\end{abstract}

Key words: financial stability, financial safety net, crisis trends, expanding, moral hazard.

\section{УТИЦАЈ КРИЗНИХ ТРЕНДОВА У БАНКАРСТВУ НА ПРОШИРЕЊЕ ИНФРАСТРУКТУРЕ СИГУРНОСТИ}

\section{Апстракт}

Стабилно и ефикасно функционисање финансијских институција, а посебно банкарских, захтева постојање одговарајућег регулаторног оквира. Разлике у карактеру и функционисању финансијских институција условиле су и разлике у регулаторним приступима за очување стабилности и ефикасности, при чему треба имати у виду да и унутар конкретног финансијског система регулаторни оквир еволуира како би одговорио новим трендовима у сектору финансијских услуга. Растућа хомогенизација активности и све мање уочљива разлика међу финансијским институцијама условила је да се зарад очувања финансијске стабилности, мрежа сигурности прошири и на небанкарске финансијске институције. Рад има за циљ да сагледа оправданост и импликације таквог проширења. С обзиром на то да „ширење” мреже сигурности стимулише ризичније понашање институција покривених осигурањем, у раду су дати предлози за управљање овим проблемом, и то у циљу да се његове размере сведу на најмању могућу меру.

Кључне речи: финансијска стабилност, инфраструктура сигурности, кризни трендови, проширење, морални хазард. 


\section{INTRODUCTION}

After extensive financial liberalizations that marked the last decades of the twentieth century, numerous changes appeared in the financial services sector. Banks lost their monopoly positions due to competition with non-bank financial institutions, which created the need for them to appear more actively on the financial market. In order to maintain the market position and stop the disintermediation trend, that is the reduced share of banks in financial intermediation, banks profiled as universal institutions. Increased consolidation in the most developed financial systems occurred not only among bank institutions, but also among non-bank financial institutions, with growing integration of international financial markets and increasing international bank activity, the formation of cross-border financial groups. Significant challenges for institutional structure were set for prevention and management of crisis. For these reasons, the paper aims at considering the implications of changes in the financial structure on the regulatory approach in maintaining financial stability. After considering the impact of current trends in banking, primarily on the change of the financial system structure, and afterwards on the expansion of the financial safety net, the final part of the paper considers such expansion embodied by moral hazard, as well as the possibilities for its management.

\section{THE IMPACT OF CURRENT TRENDS IN THE BANKING SECTOR ON CHANGE OF FINANCIAL SYSTEM STRUCTURE}

The range of the banking license determines the allowed types of operations which a certain type of a banking organization can perform according to the decision of regulatory authorities. Deposit and credit operations are operations for which banks have an exclusive license in most financial systems. However, the wave of financial deregulation after the eighties and increased competition of non-bank financial institutions have imposed the requirement for banks to be involved in operations of investment banking (operations with securities). As a consequence of such trends, two organizational models of banks have stood out: a) a separate financial system and b) a completely integrated system.

The first model is characterized by narrow specialization of banks and it implies a complete separation of commercial and investment activities. Its beginnings can be traced in US, after the Great Financial Crisis, precisely in 1933, the Glass-Steagal Act was passed, which made a strict division between commercial and investment banking (Krstić, 2003). Such a model of bank organization was sustainable up to 60 s, since banks held monopoly positions in providing financial services. However, the breakthrough of a large number of non-bank financial institutions, after the wave of financial deregulation of 70s and 80s in the last century, contributed to the formation of another model of bank organization, a completely integrated system. This 
bank model is characterized by a universal license, which implies that commercial and investment operations are performed within the same unit. The banking practice of the European Union in contrast to the American practice has always been familiar only with this type of bank organization.

Considering the fact that after the wave of financial deregulation and increased competition of non-bank insititutions disintermediation in the banking sector arose, its further existence was conditioned by being profiled as universal institutions. In this sense, it is necessary to consider the advantages and disadvantages of profiling banks as universal financial institutions.

Table 1. Advantages and disadvantages of universal banking

\begin{tabular}{ll}
\hline Advantages of universal banking & Disadvantages of universal banking \\
\hline Informational advantage & Conflict of interest \\
Increased profit through economies & Increased risks for financial stability \\
of scope and scale & \\
Greater diversification and lower risk & Difficult control of universal banks \\
\hline \multicolumn{1}{c}{ Source: adapted according to: (Claessens \& Klingebiel, 1999, pp. 5-11) }
\end{tabular}

Growing substitutability of financial services and homogenization of banking activities resulted in the formation of universal financial institutions, which are indisputably beneficial both to financial institutions and to end users of banking services. Considering the long-term relationship of banks and clients and their bilateral and highly-personified character, a universal license enabled them to reduce the costs of gathering information about the clients and their supervision, which ultimately contributed to the lower price of banking service. However, the fact that banks are in the position of a superior agent in terms of information should not be neglected and, as such, they do not need to work for their clients' interests.

A universal profile provides a bank with the possibility to use the advantage of scale economies and scope economies. By realizing numerous savings through cancelling double costs of the information system, marketing, market research and opening numerous branch offices, as well as by diversification of operations according to clients' demands, the universal bank manages to maintain its market position in an uncertain environment (Ćirović, 2007). Owing to the possibility of a bank to carry out activities with securities, the bank keeps those clients who want to look for funding sources on the capital market. Aside from guarantee profits, such a bank profile also implies a lower risk for the bank stability, considering that it reduces its incentive to enter into riskier business ventures in the pursuit of profit.

In contrast to indisputable advantages of profiling banks as universal institutions, there are numerous disadvantages. Namely, a universal bank profile carries the risk of excessive concentration of power within one institution, which certainly reduces competition on the financial services 
market. Moreover, the complexity of the organizational structure, especially the difficult separability of deposit-credit activities from investment activities of banks, leads to benefits from financial safety net, otherwise intended for banks, to be realized by investment units as well. Although this problem can be controlled to a certain extent (by introducing risk sensitive deposit insurance premium, setting aside additional capital for riskier banking activities, application of prompt corrective actions), it should be considered that control of these institutions is significantly hindered, due to different characters and objectives of regulations of deposit-credit and investment activities. In this sense, the question which arose was whether and up to which extent the bank financial safety net should be expanded in order to cover non-bank activities and institutions (Schwartz, 1992).

\section{FINANCIAL SAFETY NET}

The concern for financial stability requires a conceptualization of an adequate regulatory framework, which involves various institutions, regulations and procedures (Marinković, 2004). The so-called financial safety net is in question, within which the following components arose, by monitoring the life cycle of banks as the most significant institutions: regulation and supervision system; function of the Lender of Last Resort (LOLR); deposit insurance system and regulations for interventions or exit of banks from the system. The first component seems preventive (ex-ante) and its goal is to prevent bank bankruptcy, while the other three manage the consequences of financial instability (ex-post).

By considering the matter of which institutions should be covered by financial safety nets, two approaches arose: a) the first, which covers banks exclusively, that is depository financial institutions and b) the second, which covers a wider range of institutions.

\section{Which Institutions Should be Covered by a Financial Safety Net?}

Traditionally speaking, only banks have had a financial safety net (Todorović, 2010). Banks do not owe such a position only to its dominant position in most financial systems, but also to the fact that this is about specific (sui-generis) enterprises (Krstić, 2003). There are numerous reasons for such a standpoint (Campbell, 2008). Primarily, banks have a crucial role in the payment system. They carry out their activities in the system of fractional reserves ${ }^{1}$, in which a bank, through deposit-credit multiplication, increases the monetary base multiple times. By keeping reserves at an amount which comprises only a part of its obligations towards depositors, a

\footnotetext{
${ }^{1}$ Fractional reserve banking is a system in which bank deposits are covered by only a small part of bank reserves in relation to the bank's liabilities to depositors.
} 
bank exposes itself at risk of liquidity in case of massive withdrawals of deposits. Special sensitivity of these institutions arises from the nature of their financial structure, considering the fact that the institutions in question have, for the greater part, used borrowed capital, mostly short-term deposit sources, which makes these institutions prone to bank rush. Furthermore, the transformation of banking resources which these institutions perform (sector, currency, and especially maturity transformation) puts them at an additional risk. Having in mind their exclusive license for depository-credit operations, the interests of regulators and the financial safety net system are completely justified, predominantly for these institutions.

The assumption for activating financial safety net is management of system risk, which is most often defined as the risk of disorder in providing financial services, due to problems in the whole financial system or its components, and which has the potential to have serious negative consequences for the real secotor. Up to the 80 s of the twentieth century, banks held a monopoly position on the market of financial services in most financial systems, so this framework was adapted to them for the greatest part. However, the wave of financial deregulation which caused both the appearance of non-bank financial institutions and the expansion of banking license, increased the exposure of banks to new institutions and activities. The system risk was moved to sectors which were not regulated up to then - the sector of non-bank financial institutions.

Considering the fact that, in the beginning, bank involvement in non-bank activities was negligible, the prevailing viewpoint was that by strict control of this exposure, the risk of threatening bank stability can be kept within accepted limits, so there was no reason to expand the financial safety net to non-bank financial institutions. However, weaker regulation of non-bank institutions in the recent decades of the $20^{\text {th }}$ century stimulated banks to regulatory arbitrage, which transformed them from traditional depository-credit institutions, in which deposits were the basic funding means, into institutions which deal with loan repackaging and distribution (originate to distribute), relying more on market sources of funding (White, 2004). On the other hand, non-bank financial institutions strengthened their market positions and they became an important segment of the financial system. The consolidation between banks and non-bank institutions caused non-banking activities within financial conglomerates not to be easily separated from banking activities, whereby losses in the non-bank sector were easily transferred to banks.

During a recent financial crisis, central banks in developed countries supported not only bank and certain non-bank institutions, but also crucial segments of the market. Thus, the FED intervened by purchasing mortgage derivative securities, the ECB intervened by purchasing state-covered bonds, central banks of England and Japan intervened by purchasing state bonds. Although the support of crucial market segments contributed to their 
stability, the application of these measures must be temporary and limited. Since non-bank institutions have been supported before, especially by expost components of financial safety net, the question which has arisen is how to adapt ex-ante components to that, as well as how far should the expansion of this safety net go (Schich, 2008)?

The answer to this question requires the consideration of benefits and costs based on the expansion of the financial safety net. Namely, safety which is provided for institutions on any basis imposes the need for strengthening regulation and supervision of protected institutions, since in conditions when they count on the support of liquidity, they may be prone to hazardous behaviour. On the other hand, regulation creates costs which are reflected by mandatory reserves, proscribed level of regulatory capital and requirements for disclosure, which ultimately interferes with the functioning of the financial market. In order to secure proper development of the financial system, financial infrastructure is preferred, in which one group of institutions is covered by a financial safety net, and the other one is outside it and, therefore, it is in charge of innovation and incentives for competition on the financial services market. For these reasons, it is desirable for one group of institutions - participants on the financial market to stay outside the prudential regulation.

Due to an increased complexity of bank balance, the task of the supervisor in the estimation of the nature of the problem which the bank is facing (illiqudity or institution insolvency) is more difficult, whereby three models for organization of universal banks appeared: a) the fully-integrated banking model; b) the bank-parent model; c) the holding company model (Claessens \& Klingebiel, 1999).

The Integrated Banking Model unites commercial and investment banking within the same entity, so both the advantages and disadvantages in adopting this model are the most prominent. Within the Bank-Parent Company Model activities with securities are entrusted to subsidiaries which function as separate legal entities, so advantages and disadvantages are less prominent than in the previous model. The third model for organization of universal banks - the Holding Company Model, is characterized by separation of activities with securities from traditional banking activities into separate subsidiaries. This implies that the benefits realized by a specific subsidiary belong primarily to that subsidiary, and afterwards to the holding company. The same analogy can be applied for banking units which can be isolated from losses created in the unit which handles operations with securities. Moreover, in this model of organization the conflict of interest is sigificantly smaller, and the transfer of benefits of financial safety net to investment units is easier to limit.

An efficient banking system should be open to foreign investments (through branch offices, subsidiaries or partial ownership), especially in cases when only a few private domestic banks operate on the market. 
Highly ranked and adequately monitored foreign banks are a necessary factor in increasing competition in the banking sector, which ultimately leads to high-quality bank service. The presence of foreign banks, which is even more important, contributes to the reduction of system risk, since these institutions take great care not to be the targets of ,trust crisis“, and in this sense, they rely less on financial safety net. The freedom of foreign banks to enter the domestic bank market contributes not only to better functioning of the domestic bank market, cheaper and high-quality bank services, but also to the improvement of the regulatory and supervisory framework, reporting, through larger credibility of regulations and their harmonization with the EU regulations.

Contemporary tendencies in banking have influenced the expansion of financial safety net, not only in width, in order to cover other financial institutions by this protection system, but also in depth, in order to cover a greater range of deponents through the deposit insurance system, and within the function of the LOLR arranged by the central bank, to accept an expanded list of collaterals and counter-parties.

\section{Expansion within the Components of Financial Safety Net}

The banking sector faced tendencies after the eighties which changed the structure of the financial system and affected the expansion of the financial safety net so that it covered other financial institutions aside from banks. However, these trends had an impact on each component of financial safety net, by relativizing criteria and principles on which they are based, especially in times of crisis.

Influence on the regulation system. Until the end of the $20^{\text {th }}$ century, there was a strict regulatory regime on the market, so the supervising role was negligible. However, after the deregulation of the financial sphere at the end of the $20^{\text {th }}$ century, liberalization of financial currents followed and, therefore, the market instability of financial variables was increased (change of interest rates, foreign currencies, market prices of securities). In such conditions, banks intended to reduce levels of capital adequacy in order to increase their profitability. Considering a small percentage share of its own capital of total sources of bank funding, the first international agreement on bank capital was adopted, the Basel Capital Accord, better known as Basel I. It established a minimum rate of capital adequacy, expressed in terms of a relationship between capital and credit risk of risk-weighted assets of the bank, on the level higher than $8 \%$. Due to inadequate coverage of market risks, these standards expressed their shortcomings with first manifestations of a financial crisis in the autumn of 2008. For these reasons, the regulatory efforts were directed towards intensifying the demands on capital adequacy, which resulted in adopting a new standard on capital adequacy - Basel III. 
Table 2. Rates of capital adequacy in accordance with Basel III standard (in \%)

\begin{tabular}{lccc}
\hline No. Positions & \multicolumn{3}{c}{ Rates of capital adequacy } \\
\cline { 2 - 4 } & $\begin{array}{c}\text { Common Equity } \\
\text { Tier 1 }\end{array}$ & $\begin{array}{c}\text { Tier 1 } \\
\text { Capital }\end{array}$ & $\begin{array}{c}\text { Total } \\
\text { Capital }\end{array}$ \\
\hline 1. Minimum & 4,5 & 6,0 & 8,0 \\
2. Conservation buffer & 2,5 & & 10,5 \\
3. (1+2) & 7,0 & 8,5 & \\
4. Countercyclical buffer range & $0-2,5$ & & \\
\hline
\end{tabular}

Source: (Basel Committee on Banking Supervision, 2010, p. 63)

It can be noted in the table that the new regulatory demands gave greater importance in the capital structure to the common equity component (Common equity Tier 1, CET1) which consists of common shares issued by the bank, stock surplus, retained earnings and which must amount to at least $4.5 \%$ risk-weighted assets at all times. The new Basel standard proscribes the maintenance of a capital conservation buffer. Comprising common equity of $2.5 \%$ of risk-weighted assets, it brings the CET1 to $7 \%$ $(4.5 \%+2.5 \%)$. Since the global financial crisis is mainly the consequence of complex financial arrangements created in the process of securitization of mortgage loans, the new standard includes increase of capital for these positions as well. Special specificity of new standards can be seen in the formation of a protective contracyclical buffer within a range of $0-2.5 \%$ in comparison to the CETI, which stands out during the stable periods and periods of accelerated credit growth and it is used (released) during periods of crisis; as well as for giving an additional layer of capital for a systemically important financial institution (ranging from 1-2.5\%, depending on a bank's systemic importance) (Bašić, 2012).

For the purpose of liquidity risk management, there are two indicators: the liquidity coverage ratio (LCR), as a measure of bank resistance to shortterm liquidity shock, by keeping sufficent high-quality liquid assets to wthstand a 30-day stressed funding scenario, and the net stable funding ratio (NSFR), as a measure of bank resistance to the long-term liquidity shock, by keeping the part of capital and bank liabilities which are expected to be stable sources of funding for the period of one year (Basel Committee on Banking Supervision, 2014). Considering the increased exposure of banks towards certain banking activities (investment into specific sectors or branches, crediting bank-related parties, keeping open positions in certain currencies), as well as towards the non-bank sector, the standard defines a maximum level of bank exposure according to these positions.

Influence on the function of lender of last resort. LOLR implies a system of bank liquidity control and a system for support of banks with threatened liquidity, which is most frequently organized by the central monetary institution. This type of liquidity support is activated after the 
depletion of bank liquidity reserves and the conditions of intervention of $\mathrm{CB}$ is a system illiquidity of the banking sector, not the problem of individual banks. Although this type of support is reserved for solvent institutions with a temporary liquidity problem, in practice it is very difficult to make a difference between illiquidity and insolvency, so this type of support is usually given to insolvent banks as well. Certainly, it is assumed that the institution will, although being insolvent, succeed in solving its financial problems in short term. For these reasons, with a guarantee of liquidity, the need for adopting an adequate program for bank restructuring occurs regularly. In this case, constant communication with supervisory authorities is required. In this way, institutions which are close to the insolvency zone are identified timely, and a greater influence of this type of support for bank liquidity on efficiency of the monetary policy is avoided, as well as cumulation of losses in CB.

Walter Bagehot (1873), a British economist, set orthodox criteria for borrowing from $\mathrm{CB}$ in the $19^{\text {th }}$ century, in accordance with which the CB should allow a short-term credit for liquidity to a solvent institution if it is ready to pay penalty (higher than the market) interest rates and pledge a good collateral. During the crisis period, it is very difficult to identify the problem which the bank is facing, and departure from these criteria is very common. Namely, the inability of banks to borrow on the interbank market, as well as the lack of quality collateral for borrowing from CB, is already a sufficient signal that an illiquid institution is simultaneously insolvent or that it is going to become such soon (Goodhart, 1999, pp. 340-341).

Intensive growth of non-bank institutions and their connection to banks have significantly hindered the limitation of liquidity support exclusively to banks. Such an approach would be too narrow and inconsistent with the existing structure and development of financial institutions and the whole financial system, especially in conditions of a crisis (Dobler, et al., 2016). Significant reliance of deficit transactors on non-bank mediators, on mutual funds and money market mutual funds contributed for these institutions during the recent financial crisis to be provided with a significant liquidity within the LOLR arrangement. Having in mind that transactors saw an alternative in the products of these institutions for bank deposits, they invested in them both as individual and as institutional investors. However, the moment there was doubt that these instruments could not easily be converted into cash, they became the subject of rush like the bank deposits. In providing LOLR support, CB must be cautious and directed towards a smaller number of counter-parties.

A special position is given to dealers with government securities, since the market for these securities is the most important segment of the money market as the transmission mechanism of monetary policy and funding of the state. The role of the dealer is significant also on the market for private securities, where LOLR takes the form of an asset swap, providing the 
possibility to exchange less liquid private sector bonds for more liquid government bonds (Dobler, et al., 2016). In these cases, non-bank institutions as a LOLR users are subject to a special system of control, whereby they do not become the subject of direct regulation and control of $\mathrm{CB}$, but information exchange is performed on the basis of Memoranda of Understanding, MOUs.

The lending policy of central bank is modified not only in providing credit support to a greater number of institutions, but also towards relaxation of the lending criteria (extension of deadline for arrangement, payment of lower interest rates and accepting inadequate collateral). Such a relaxation is justified only in the case when bankruptcy of a certain institution or another component of the financial system has a system significance ${ }^{2}$, that is the potential to threaten financial stability. In such cases, LOLR support is often combined with an adequate plan for bank restructuring, which will in the shortest time period enable further operations of a currently insolvent institution. In the meantime, $\mathrm{CB}$ can demand compensation from the state for the created losses so that it would not be forced to monetize the loss created due to providing LOLR support.

Internationalization of bank activities caused a coordination problem of regulatory efforts, considering that regulatory authorities from various countries are responsible for infrastructure. Considering the fact that branch offices do not have legal subjectivity, lincensing and monitoring them is under the jurisdiction of the regulatory authority of the home country ${ }^{3}$, whereas the subsidiary, in terms of its legal subjectivity, is under the jurisdiction of the regulatory authority of the host country. Since, in case of branch offices, the regulatory authority of the host country do not have sufficient information about the solvency of branch offices, approving credits within the LOLR arrangements to the entity which is a part of an international group can be very risky (Guttentag \& Herring, 1983). In that case, communication and coordination among national regulators is necessary, which is hindered and is subject of negotiation in conditions of crisis. Cases in which a subsidiary has a problem of insufficient funds in a

\footnotetext{
${ }^{2}$ Evaluation of the systemic significance of a certain institution is a complex activity and it implies the evaluation of an institution according to several aspects: size, measured by market share of depository-credit activities, share of non-bank activities, significance for payment system; complexity and substitutability of banking services; degree of connection with other institutions; infection risk (Dobler, et al., 2016, p. 23).

${ }^{3}$ Home country is determined according to the headquarters of bank management and location in which most bank activities are performed. However, in a situation when majority of transactions are performed at a location which differs from the headquarters of management, a problem arises in determining the responsible supervisor. In that sense, in order not to have several supervisors qualified for monitoring affairs from home countries, the primary criteria which is taken into account is the headquarters of bank management.
} 
situation when the parent bank does not provide an adequate support for its subsidiary, or when support is needed by the parent bank, in which deleveraging process is present, that is the flow of funds from the subsidiary to the parent bank, are not rare. A special problem for LOLR is present in countries which are characterized by high levels of currency substitution, that is, application of foreign currency as means of payment in formal and informal transactions (Fabris, 2008, p. 87). Although the presence of deposit in "hard currency" reduces the possibility of emergence of a system crisis, in situations when a crisis emerges, these economies are more sensitive to transfering negative signals from the external environment (Marinković \& Jemović, 2011, p. 119). As the presence of currency substitution denies the central bank privilege of money creation, it will be able to step forward as a guarantee of bank liquidity only if it had a significant amount of foreign currency reserves. If this is not the case, import of LOLR by the issuer of the reserve currency stands out, or multilateral organizations, such as the International Monetary Fund.

Influence on the deposit insurance system. Deposit insurance represents a significant component of financial safety net of the bank sector, since the main part of liabilities of banks are comprised of deposit sources. In case of bankruptcy, this guarantees payment of deposits and a long-term bankruptcy proceedings are avoided. Since in most financial systems banks are the only institutions with depository-credit license, they are the only ones which are responsible paying the provided insurance premium for such safety. There are numerous issues and dilemmas which should be resolved in the operationalization of the deposit insurance system: a) Should the deposit insurance system be established as explicit or implicit?; b) Is the formation of a special fund for funding necessary?; c) Should the premium be payed in advance (ex-ante) or after an insured case (ex-post)?; d) Should the premium be linear for all banks or adjusted to risk?; e) The range of agency authorization for deposit insurance!; g) Level of deposit insurance coverage in terms of type of financial institutions, deposit category, coverage amount and many other issues.

After the establishment of the first agency for deposit insurance in the US (Federal Deposit Insurance Corporation, FDIC) the deposit insurance system has been introduced as explicit in a growing number of countries after the eighties. Operationalization of the deposit insurance system according to the stated issues resulted in the formation of quite different deposit insurance systems. Nevertheless, the influence of mutual factors on the deposit insurance system (current trends in banking and crisis environment) contributed to the development of all deposit insurance systems to be performed towards providing a greater degree of deposit protection.

Along with the internationalization of banking activities and the formation of a unique EU market, the process of regulation harmonization followed, by which stability of a unique banking market was guaranteed. 
Efforts are directed towards formation of a banking union, which rests upon three pillars: the Single Supervisory Mechanism, SSM; the Single Resolution Mechanism, SRM; and the European Deposit Insurance Scheme, EDIS. The first two pillars of the banking union, the SSM and SRM have already been established, whereas a proposal for consideration for the third one was made in November, 2015. Since an adequate answer of EU Member States was not provided during the recent financial crisis, due to significant differences of national schemes for deposit insurance, a new text Directive on Deposit Insurance (2014/49/EU) envisages an increase of the insured amount, coverage of a wider deponent category, cancellation of co-insurance, deposit payment in a short term, as well as introduction of deposit insurance in countries where such a system was not introduced.

Considering the fact that payment of insured deposits is related to the initiation of bankruptcy or liquidation proceedings in an insolvent institution, it is very important for the rules governing intervention in the banking sector to be clearly defined. This is especially important in those situations when these operations are under the jurisdiction of somebody else than the Agency for deposit insurance, as is the case in most EU Member States. An intensive globalization and homogenization process and the formation of financial conglomerates has significantly made the regulatory approach to maintaining financial stability more complex, considering the fact that institutions are internationalized, but the regulation is not (Garcia, et al. 2009). For these reasons, the need for supervisor cooperation and acknowledgement of foreign decisions in situations when insolvency of global finanical institutions occurs. The need to expand the financial safety net in order for it to adapt to the changed structure of the financial system, as well as to the crisis conditions, although having the function of providing financial stability, can reduce cautiousness of banks, deponents and the regulatory authorities themselves and make the system vulnerable. Namely, through an inadequately conceived system for maintaining financial stability, a high level of safety is achieved, which intensifies the tendency for overtaking risk up to the extent to which the system itself becomes the reason for financial system destabilization. In this sense, it is necessary to establish adequate mechanisms for discouragement of hazardous behaviour in every subsystem of financial safety nets.

\section{POSSIBILITIES FOR MORAL HAZARD MANAGEMENT}

Moral hazard is the side effect of every situation in which knowledge about the existence of an institution or mechanism to which risk can ultimatively be transferred, makes the system prone to overtaking higher levels of risk in the future periods (Ahec-Sonje, 2002). Management mechanisms for this problem imply specific aspects of regulation, the application of which can influence the suppression of moral hazard in several 
components at the same time. For instance, rigorous sanctioning of disrespect of prudential standards reduces the range of moral hazard in other components of financial safety net.

It is necessary to be especially cautious so that the final effect of regulation oriented towards the maintainance of stability of financial institutions and market does not result in decreased efficiency of sector functioning. A practical illustration is made for solutions of structure regulation oriented towards ring-fencing crucial banking (deposit) activities and proscribing more strict regulatory requirements for riskier business activities of banks. Although it is directed toward maintenance of stability of the banking sector, these solutions reduce the diversification of banking services and, therefore, the profitability of the banking sector as well. In addition, the separation of activities within a bank in two separate departments increases operative risk, despite the fact that it reduces market risk. Since the financial safety net was considered according to components, by monitoring the life cycle of a bank, mechanisms for suppression of moral hazard are outlined according to components.

Table 3. Mechanisms for suppression of moral hazard caused by existence of financial safety net

\begin{tabular}{|c|c|c|c|c|c|}
\hline $\begin{array}{c}\text { Financial } \\
\text { safety net }- \\
\text { components }\end{array}$ & \multicolumn{6}{|c|}{ Mechanisms for suppression of moral hazard according to components of } \\
financial safety net
\end{tabular}

Although present within the regulation and supervision systems, moral hazard is more prominent in ex-post components of financial safety net. Inserting additional liquidity into the banking system by the central bank is the most common way of stabilization of the banking system. However, Bagehot himself, as the founder of the LOLR function asserts that if adequate measures of caution are not taken, guarantee of liquidity by the central bank can be worsened rather than be able to reduce the potential of a financial collaps. In this sense, defining strict conditions for lending is suggested (penalty interest rates with good collateral), hesitation of regulators to provide credit support, strengthening of regulation and 
supervision of bank activities and forming a club of bankers in which hazardous behaviour is unforgivable (Moore, 1959).

Despite the undistuped significance of the deposit insurance system, too broadly set deposit insurance system reduces caution of deponents and the bank, which ultimately has destabilizing effects. In order to reduce the measures of moral hazard to reasonable amounts, connecting insurance premium to the risk level is suggested; leaving one part of the deposit uninsured (co-insurance); limiting amounts and insurance coverage; strengthening market discipline through introducing subordinary debt instruments (Protić, 2002).

For the purpose of faster and more efficient implementation of bank restructuring procedure, introducing specific rules for procedure implementation in insolvent banks is suggested. This is about the special resolution regime (SRR) which, besides instruments for crisis management, includes instruments which act preventively (Swire, 1992). The existence of a credible framework for restructuring is particularly significant in banks, especially the ones marked in the system as systemically significant. Restructuring measures must be applied long before it comes to its balance insolvency, so the rules for regulatory intervention often combine hard and soft criteria. The framework for bank restructuring should be conceived in a way to protect critical participants and bank functions, such as deponents, investors and the payment system; but not uninsured creditors and shareholders who bear the losses in accordance with the defined priorities, which would otherwise be valid in bankruptcy proceedings. In order to control moral hazard based on the activity of restructuring, it is suggested for these affairs to be funded at the expense of shareholders' and bank creditors' funds, and not by using public funds. It is necessary to make sure that shareholders and creditors do not answer to the introduction of such measures by increasing the equity price.

A significant source of moral hazard is the banking license, in the sense that a broad license stimulates riskier behaviour of a bank. Considering the fact that in the banking system a universal concept of the bank is dominant, as well as the fact that banks are more connected to the non-bank financial institutions, the possibility of implementing disciplinary measures is hindered (Žiravac-Mladenović, 2013). The current financial crisis has put to test the concept of universal banking and the entry of banks into risky operations with securities has once again been identified as the basic crisis cause. In that sense, suggestions are directed towards introducing the concept of narrow banking, which is based on the former strict divison between commerial and investment banking. According to the former president of Federal Reserves, this rule was named "Walker's rule" and it assumes that American banks, their affiliations and holding companies must not perform proprietary trading or enter any form of partnership with hedge funds and risky capital funds. This rule did not 
abolished universal banking, but the level of speculative assets which the bank is allowed to own is limited to $3 \%$ of total assets.

However, the hotspot of the crisis was not the banking sector, but the non-banking sector, institutions which were trying to avoid the traditional banking regulation and, therefore, were left without the possibility to enjoy the benefits of financial safety net. However, during the recent financial crisis, non-bank institutions (money market mutual funds, broker-dealer organizations) proved to be very sensitive to rush, so regulatory authorities reacted ad-hoc, providing support to liquidity and guaranteeing uninsured responsibilities of certain institutions. For these reasons, the question was made of whether intervention of this type should be part of measures in the future? In US, regulatory efforts are being made which imply prudential regulation of non-bank institutions, which are marked as systemically significant by the Federal Reserves. Certainly, the question arises how to deal with broker-dealer organizations which are not marked as systemically significant, considering that they were not the subject of prudential control?

\section{CONCLUSION}

Financial safety net is traditionally reserved for banks considering their sensitivity to crisis liquidity, as well as possible system consequences of bank bankruptcy. In this sense, the components of financial safety net follow the life cycle of banks and they include: regulation and supervision systems, LOLR function, deposit insurance system and rules for managing interventions in the banking system and for regulating the exit of banks from the system. The wave of financial deregulation which marked the last decades of the $20^{\text {th }}$ century caused the increase of consolidation and internationalization of the financial services market, which resulted in a smaller difference between financial institutions. In this process, banks have increased and expanded its activities to non-traditional banking actitivites, whereas non-banking acitivities have entered the segment of traditional banking activities on various grounds. In such conditions, it has become more difficult to limit the financial safety net exclusively to banks, especially considering the fact that banks have been exposed more to non-bank institutions and activities. Internationalization of banking activities was not accompanied in the same extent by the internationalization of regulation and, therefore, the need for global coordination of banking regulation has arisen.

Analyses indicate that the formation of universal financial institutions through various organization forms provides benefits both for the institutions themselves, as well as for the end users of banking services. What has arisen as an issue here is how to successfully control that the benefits from financial safety net go to non-bank institutions, which have not paid certain 
regulation costs for such a type of protection. During the recent financial crisis, financial safety net covered certain non-bank institutions, which are evaluated by regulators as important for preserving financial stability. In order to prevent regulatory authorities in the future to act ad hoc and depending on the case, it is necessary that non-bank financial institutions are subject to prudential control. In this way, the response of regulatory authorities will be more credible, and moral hazard less expressed.

\section{REFERENCES}

Ahec-Šonje, A. (2002). Analiza osetljivosti bankarskog sustava - primjena signalne metode. Ekonomski pregled [Analysis of the banking system's vulnerability application of the signaling method]. Economic review, 53(9-10), 807-848.

Asanović, Ž. (2013). Formulisanje i primjena modela ranog upozorenja sistemskih bankarskih kriza u Crnoj Gori [Formulation and implementation of the early warning system for systemic banking crises in Montenegro], doktorska disertacija. Ekonomski fakultet, Univerzitet Crne Gore.

Bagehot, W. (1873). Lombard Street: A Description of the Money Market. New York: Scribner: Armstong \& Co.

Basel Committee on Banking Supervision. (2010). Basel III: A Global Regulatory Framework for More Resilent Banks and Banking Systems. Bank for International Settlements.

Campbell, A. (2008). Insolvent Banks and Financial Sector Safety Net. Singapore Academy of Law Journal, 316-342.

Claessens, S., \& Klingebiel, D. (1999). Alternative Frameworks for the Provision of Financial Services Economic Analysis and Country Experiences. World Bank Policy Research Working Paper, 2189. Preuzeto sa https://ssrn.com/abstract= 623943

Ćirović, M. (2007). Bankarstvo [Banking], Beograd: Naučno društvo Srbije.

Dobler, M., Murphy, D., \& Radzewicz-Bak, B. (2016). The Lender of Last Resort Function after the Global Financial Crisis. IMF Working Paper, 10.

Fabris, N. (2008). Evroizacija u Crnoj Gori - prednosti, nedostaci i ograničenja. Kvartalni monitor ekonomskih trendova $i$ politika u Srbiji [Euroization in Montenegro - advantages, disadvantages and limitations. The Quarterly Monitor of Economic Trends and Policies in Serbia], 11, 87-94.

Garcia, G., Lastra, R., \& Nieto, M. (2009). Bankruptcy and reorganization procedures for cross-border banks in the EU - Towards an integrated approach to the reform of the EU safety net. Journal of Rinancial Regulation and Compliance, 17(3), 240-276.

Goodhart, C. (1999). Myths about The Lender of Last Resort. International Finance, 2, 339-360

Guttentag, J., \& Herring, R. (1983). The Lender of Last Resort Function in an International Context. Essays in International Finance, 151.

Krstić, B. (2003). Bankarstvo. [Banking], Niš: Ekonomski fakultet.

Marinković, S. (2004). Infrastruktura sigurnosti finansijskog sistema: predlog reforme. Bankarstvo [Financial safety net: reform proposal. Banking], 5-6, 14-26.

Marinković, S. (2008). Finansijsko tržište i finansijske institucije u Republici Srbiji. [Financial market and financial institutions in the Republic of Serbia], Niš: Ekonomski fakultet. 
Marinković, S., \& Jemović, M. (2011). Funkcija poslednjeg utočišta i valutna supstitucija: problemi i rešenja. Unapređenje konkurentske prednosti javnog $i$ privatnog sektora umrežavanjem kompetencija u procesu evropskih integracija Srbije [The Lender of last resort and currency substitution: problems and solutions. Improving the competitive advantage of the public and private sector by networking competencies in the process of European integration of Serbia], 115-134, Niš: Ekonomski fakultet.

Moore, G. (1959). Solutions to the Moral Hazard Problem Arising from the Lenderof-Last-Resort Facility. Journal of Economic Surveys, 13 (4), 443-476.

Protić, M. (2002). Osiguranje depozita i problem moralnog hazarda (primer nemačke šeme privatnog osiguranja depozita). Industrija [Deposit insurance and the problem of moral hazard (the example of the German private deposit insurance scheme). Industry], 30(1-4), 23-32. http://scindeks-clanci.ceon.rs/data/pdf/03500373/2002/0350-03730201023P.pdf

Schich, S. (2008). Financial Crisis: Deposit Insurance and Related Financial Safety Net Aspects. Financial Market Trends, OECD.

Schwartz, A. (1992). The Misuse of the Fed's Discount Window. Economic Review, $58-69$.

Swire, P. (1992). Bank insolvency law now that it matters again. Duke Law Journal, 42(3), 469-556.

Todorović, V. (2010). Regulativa banaka i bankarske krize [Bank regulation and banking crisis], doktorska disertacija. Kragujevac: Ekonomski fakultet.

White, W. (2004). Are Changes in Financial Structure Extending Safety Nets? BIS Working Papers, 145.

Žiravac-Mladenović, M. (2013). Razlozi i interesi za regulaciju banaka. Međunarodna konferencija o društvenom $i$ tehnološkom razvoju STED [Reasons and interests for regulation of banks. International Conference on Social and Technological Development STED], 2, 120-134.

\title{
УТИЦАЈ КРИЗНИХ ТРЕНДОВА У БАНКАРСТВУ НА ПРОШИРЕЊЕ ИНФРАСТРУКТУРЕ СИГУРНОСТИ
}

\author{
Мирјана Јемовић, Борко Крстић \\ Универзитет у Нишу, Економски факултет, Ниш, Србија
}

Резиме

Након опсежнијих финансијских либерализација које су обележиле последње деценије прошлог века, уследиле су бројне измене у сектору финансијских услуга. Банке су изгубиле монополску позицију услед конкуренције небанкарских финансијских институција, што је створило потребу за њиховим активнијим наступом на финансијском тржишту. У циљу очувања тржишне позиције и заустављања тренда дезинтермедијације, банке су се профилисале као универзалне институције. Појачана консолидација у најразвијенијим финансијским системима одвијала се не само између банкарских већ и између банкарских и небанкарских институција, а са растућом интеграцијом међународних финансијских тржишта и повећањем међународних активности банака, дошло је до формирања прекограничних финансијских група. Овиме су постављени значајни изазови пред институционалну структуру за превенцију и управљање кризом. 
Очување финансијске стабилности захтева постојање тзв. инфраструктуре сигурности (financial safety net), која укључује бројна правила, механизме и институције. Традиционално, ова инфраструктура покривала је искључиво банке, како због њихове доминантне позиције на тржишту финансијских услуга тако и због специфичне природе ових институција. Пратећи животни циклус банака, издвојили смо следеће компоненте инфраструктуре сигурности: систем регулације и супервизије, функција последњег уточишта, осигурање депозита и правила којима се руководи интервенција и излазак банака из система. Талас финансијске дерегулације, који је условио како појаву небанкарских финансијских институција тако и ширење банкарске лиценце, повећао је изложеност банака новонасталим институцијама и активностима. Системски ризик је пребачен у до тада нерегулисане секторе, што је утицало на проширење инфраструктуре сигурности, и то не само како би се њоме покриле и друге финансијске институције већ и како би се релативизацијом критеријума пружио већи степен заштите.

Проширење инфраструктуре сигурности како би она одговорила измењеној структури финансијског система, као и условима кризе, иако у функцији обезбеђења финансијске стабилности, смањило је опрезност банака, депонената, а и самих регулаторних органа, те тиме учинило систем рањивијим. С обзиром на специфичност компоненти инфраструктуре сигурности, у раду је дат предлог механизама за дестимулисање хазардног понашања у сваком од подсистема мреже сигурности. Притом, конципирање адекватног регулаторног оквира за очување стабилности сектора финансијских услуга не сме имати за последицу смањену ефикасност овог сектора. 